\title{
Pathology and Molecular Diagnosis of White Spot Syndrome Virus (WSSV) among Vannamei Shrimp in Egypt
}

\author{
Aly S. M. (1), Shimaa M. Mansour ${ }^{(2)}$, Randa Y. Thabet ${ }^{(3)}$ \\ (1) Department of Pathology, Faculty of Veterinary Medicine, Suez Canal \\ University. (2) Department of Virology, Faculty of Veterinary Medicine, \\ Zagazig University. (3) Department of Aquaculture Diseases Control, Fish \\ Farming and Technology Institute, Suez Canal University.
}

\begin{abstract}
White spot syndrome virus (WSSV) is poorly understood as no available information regarding its possible spread among shrimp cultured in Egypt. Therefore, this work aimed to diagnose WSSV in cultured shrimp by pathological examination and molecular based methods (PCR). A total of 20 shrimp samples were collected from shrimp farms in Egypt. Diseased shrimps exhibited sudden mass mortalities and showed loose cuticle with numerous scattered melanised visible white spots on external surface. Histopathological examination revealed nuclear hypertrophy with eosinophilic (Cowdry A inclusion) to basophilic inclusions in the internal organs (connective tissues). Spheroids were observed in the lymphoid tissues. Cell encapsulation was accompanied by pyknosis and karyorrhexis. PCR results with primers specific for WSSV gave a predicted amplified product at $414 \mathrm{bp}$ fragments using agarose gel electrophoresis. The present findings request more investigations for White spot syndrome virus disease among shrimp in Egyptian farms and recommend the establishment of preventive measures against this virus in Egypt.
\end{abstract}

Key words: Shrimp, Egypt, WSSV, Histopathology, Molecular detection, PCR, Phylogenetic analysis.

\section{Introduction}

Shrimp is one of the most traded seafood products worldwide, occupying about $14 \%$ of the total value of fishery products. Shrimp farming is one of the main forms of global shrimp production with an increase in contribution from $6 \%$ in 1970 to $83 \%$ in 2016 and has become a 'booming' business
(FAO, 2018). Shrimp farming provides a major source of income for farmers and plays a potential role in the poverty alleviation in developing countries (Lewis et al., 2003). A large number of pathogens threaten the shrimp aquaculture industry with a majority of these being viral in etiology with major economic 
losses (Lightner et al., 2012). The emergence of novel pathogens is inevitable because of the combined effects of high intensity farming and a globalized aquaculture industry that exports and imports either live or unprocessed products and thereby rapidly disseminate pathogens worldwide (Loy et al., 2015). Different life stages of shrimp may be susceptible to certain viral infections that causing mortality, slow growth and deformations. There are more than 20 viruses have been reported as shrimp pathogens that cause disease reducing shrimp yields, and six viruses of marine cultured shrimp are currently listed as notifiable by the united organization for Animal Health (OIE-2012) (Walker and Winton 2010, Stentiford et al., 2012). White spot syndrome virus (WSSV) among the major viruses of concern that responsible for serious production losses (Lightner, 2011; Ganjoor, 2015).

In Egypt, shrimp industry are steadily progressed to meet the market demands specially in the coastal area, but the high risk of virus infection in shrimp farms might be affect the production (Eissa et al., 2009). White spot syndrome virus in Egyptian shrimp is poorly understood. To our knowledge, there is no available information regarding possible viral infection of shrimp in Egypt. Therefore, the main goal of this work aimed to diagnose WSSV in shrimp cultured in Egypt.

\section{Materials and methods:}

Twenty samples (musculature, haematopoietic tissues, gills, lymphoid tissue, and cuticles) of clinically infected shrimp were obtained from Egyptian farms and lakes during 2017 and used for histopathological examination, molecular detection and sequencing. Specimens were collected from two regions located at the coast of Mediterranean Sea (farms at Mothalath El-Deba, Damietta Province \& Bardaweil Lake, North Sinai Province).

\section{Histopathological examination:}

The shrimp tissues were cleaned, washed three times in sterile distilled water and dried thoroughly with sterile towels before exposure for anatomy and collection of internal organs. The cuticles of moribund shrimp were splitted sagittally using a surgical scalpel and scissors. A part of some internal organs of shrimp specimens fixed in Davidson's Solution for histopathological examination. Cut sectioning passing through the cuticle, gills, heart, hepatopancreas, lymphoid tissues, stomach and gut were taken and fixed in Davidson solution (pH 3.5 to 4) according to Vijayan and alavandi (2005). Tissues were processed and histopathological section were prepared and stained with $H \& E$ according to the protocol of Bell and Lightner (1988). 
DNA extraction:

The procedure for total genomic of White spot syndrome virus (WSSV) was done according to manufacturer protocol of Omega Co. (USA.LMt.):

1. To $100 \mathrm{mg}$ powdered tissue of infected shrimp, add $550 \mu \mathrm{L}$ of lysis buffer solution were added, shacked gently, incubated for $30 \mathrm{~min}$ on ice, and centrifuged at $1200 \mathrm{rpm}$ for 10 $\min$ at $4^{\circ} \mathrm{C}$.

2. Supernatant was Removed (tissues waste), $1 \mathrm{ml}$ lysis buffer was added, the pellet was resuspend, and centrifuged for 10 $\min$ at $4^{\circ} \mathrm{C}(1200 \mathrm{rpm})$.

3. Supernatant was removed (tissues waste), $0.5 \mathrm{ml} \mathrm{SE}$-buffer was added, the pellet was resuspend, followed by centrifugation for 10 minutes at $4^{\circ} \mathrm{C}(1200 \mathrm{rpm})$.

4. Supernatant was removed (tissues waste). (It is possible to store the pellet at $-80^{\circ} \mathrm{C}$. Centrifuge at 1200 rpm for $10 \mathrm{~min}$ at $4^{\circ} \mathrm{C}$. The supernatant was removed and the pellet was freezed). $1 \mathrm{ml} \mathrm{SE-buffer}$ was added and the pellet was resuspend, $40 \mu \mathrm{l}$ proteinase $\mathrm{K}(10$ $\mathrm{mg} / \mathrm{ml}$ ) was added and $250 \mu 120 \%$ SDS, shaked gently, and incubated overnight at $37^{\circ} \mathrm{C}$ in a water bath.

5. A $5 \mathrm{ml} \mathrm{SE-buffer} \mathrm{was} \mathrm{added} \mathrm{and}$ $10 \mathrm{ml}$ phenol shaked by hand for 10 min, and centrifuged at $3000 \mathrm{rpm}$ for $5 \mathrm{~min}$ at $10^{\circ} \mathrm{C}$.

6. The supernatant was transferred into a new tube, $1 \mathrm{ml}$ phenol/chloroform/ isoamyl alcohol (25:24:1) was added, shaked by hand for $10 \mathrm{~min}$, and centrifuged at $3000 \mathrm{rpm}$ for $5 \mathrm{~min}$ at $10^{\circ} \mathrm{C}$.

7. The supernatant again was transferred into a new tube, $1 \mathrm{ml}$ chloroform/ isoamylalcohol (24:1) was added, shake by hand for 10 min, and centrifuged at $3000 \mathrm{rpm}$ for $5 \mathrm{~min}$ at $10^{\circ} \mathrm{C}$.

8. The supernatant was transferred into a new tube; $100 \mu 13 \mathrm{M}$ sodium acetate ( $\mathrm{pH} 5.2$ ) was added and 10 $\mathrm{ml}$ isopropanol, shaked gently until the DNA precipitated, use a glass pipette, make a hook over a Bunsen burner, and capture the DNA.

9. The DNA was washed in $70 \%$ ethanol and dissolved the DNA in $0.1 \mathrm{ml}$ TE-buffer overnight at $4^{\circ} \mathrm{C}$ on a rotating shaker. (If the DNA is not dissolved leave it longer at $4^{\circ} \mathrm{C}$ on the rotating shaker).

\section{Gene amplification reaction} conditions for WSSV gene:

Oligonucleotide Primers were as follows according to Saberi et al. (2008) for WSSV

F 5' TCCAAACACAAGTGTGTTGATC 3';

R 5' AAGACGCCTACCCTGTTGAATC 3'.

That was targeting (414 bp) the complete ORFs of vp24 of WSSV

PCR amplification:

Specific DNA was amplified through GeneAmp Polymerase Chain Reaction (Creacon, Thermo cycler, Holand) system cycler. PCR for amplified genomic DNA was carried out. The cycling parameters for the second step reaction were 1 cycle at $95^{\circ} \mathrm{C}$ for $2 \mathrm{~min}$ followed by 39 cycles of $95^{\circ} \mathrm{C}, 65^{\circ} \mathrm{C}$ and $72^{\circ} \mathrm{C}$ for $30 \mathrm{~s}$ each and a final extension 
at $72^{\circ} \mathrm{C}$ for 2 min (Poulos and Lightner, 2006).

Agarose gel electrophoresis and detection of the amplification products:

$1.5 \%$ agarose solution was prepared by adding $0.75 \mathrm{~g}$ agarose to $50 \mathrm{ml}$ of $1 \mathrm{x}$ TBE electrophoresis buffer in $50 \mathrm{ml}$ flask. Heating in a microwave oven then dissolved the agarose. The agarose was cooled in $50^{\circ} \mathrm{C}$. A comb was inserted in electrophoresis bed and the agarose was poured in it. Great care should be taken during pouring of the agarose to avoid bubbles formation. The gel solidified within $15 \mathrm{~min}$ and became cloudy, the electrophoresis apparatus was filled with the electrophoresis buffer and the comb was removed creating 6 or 10 wells for sample application. Electrodes were connected to the power supply and the later was turned on. It was adjusted at 80 Volts for $100 \mathrm{~min}$. The gel was removed from its bed and transferred to the gel staining tray for staining with Ethidium bromide for $30 \mathrm{~min}$ followed by $20 \mathrm{~min}$ distain in distilled water. Specific DNA bands were eluted from agarose gel. Resultant PCR products were purified with Micro spin filters (E.Z.N.A.®Gel Extraction Kit, D2500-01, OMEGA bio-tek, USA) and quantities spectrophotometrically. Sequence analysis was employed using the ABI PRISM ${ }^{\circledR} \quad 3100 \quad$ Genetic Analyzer (Micron-Corp.Korea).
The purified PCR products were sequenced using the same forward and reverse primers used in PCR (Delta

Scientific

Consultancy Center, Alexandria, Egypt). Forward and reverse sequences were aligned together to generate a consensus sequence using DNA Baser Sequence Assembler version 4.36 (http://www.dnabaser.com/). The obtained sequences were further identified by nucleotide BLAST (http://www.ncbi.nlm.nih.gov/BLA ST).

\section{Data analysis}

Sanger sequencing and Phylogenetic analysis:

Gel documentation system (Geldocit, UVP, England), was applied for data analysis using Totallab analysis software, ww.totallab.com, (Ver.1.0.1). Aligned sequences were analyzed on NCBI website (http://www.ncbi.nlm.nih.gov/webc ite) using BLAST to confirm their identity. The Genetic distances and MultiAlignments were computed by Pairwise Distance method using ClusteralW software analysis (www.ClusteralW.com). The nucleotide sequences were also compared with other related sequences available in the GenBank. The phylogenetic tree was generated using neighbourjoining method employing the Kimura 2-parameter correction in MEGA version 5 (www.megasoftware.net) by aligning the nucleotide sequence of virus genes with other sequences 
available in the GenBank with 1,000 bootstrap analyses.

\section{Results}

Diseased shrimps exhibited a marked reduction in food consumption, followed by changes in behavior and appearance. The first recognizable signs in infected shrimps were lethargic surface swimming followed by motionless, inverted sinking to the bottom, muscle opacity, lack of mobility and death. Sudden massive mortalities was noticed with loose cuticle that easily separated from the underlying epidermis with the presence of numerous scattered melanised visible white spots on external surface (Figure 1), it was more prominent and clear on the inside surface with some cuticular deformities and opaque muscles. White spots appear in carapace and cephalothorax and its sizes varied from rounded pinpoint minute dots to spots (discs) of $3 \mathrm{~mm}$ in diameter. They coalesce to each other to form patches of variable size whitish circular spots (Figure 1, Table 1). The spots mostly located on the inside surface of the cephalothorax and can't scraped-off with the thumbnail and most easily observed by removing the cuticle over the cephalothorax.

Hepatopancreas become yellowishwhite with swollen and fragile texture. Darkening of muscles was evident. Hemolymph was thin, hyperemic and delayed or failed to coagulate; the gills are foul odor and loss its preening look. Lymphoid organ may be swollen and shrunken. Swollen of bronchiostegites was seen due to accumulation of fluid. Affected shrimps appeared brown-reddish in color due to expansion of the cuticular chromatophores (Figure 2).

\section{Histopathological changes}

The histopathology of infected cells (connective tissue, muscle, gills, lymphoid tissue) was characterized by nuclear hypertrophy with eosinophilic (Cowdry A inclusion) to basophilic inclusions.

In severe infections by WSSV, pyknosis and karyorrhexis of infected cells (connective tissue, muscle, gills, lymphoid tissue) were evident. The affected tissues showed loss of structure with spongy connective tissue beneath the stomach cuticular epithelium and in the haematopoietic tissue. Encapsulation of infected cells (connective tissue, muscle, gills, lymphoid tissue) was observed in some infected shrimps.

The encapsulation was not accompanied by melanization and the adjacent tissues did not show lesions that could be attributed to inflammatory foci. This condition was more evident in the spongy connective tissue basal to the stomach cuticular epithelium (Figure 3, Table 2). PCR results of WSSV in shrimp samples

PCR results with primers specific for the gene encoding gave a 
predicted amplified product at 414 bp fragment, respectively by agarose gel electrophoresis as observed in Figure (4). These samples represent isolates from two localities in Egypt including; Bardaweil Lake and Mothalath El.Deba.

The DNA of WSSV was detected in $5 / 8(62.5 \%)$. Regarding to locality, the WSSV was detected in $75 \%$ of examined samples in Mothalath El.Deba and $50 \%$ in Bardaweil Lake.

\section{Sequences and phylogenetic analysis of WSSV:}

To assess genetic characteristics of WSSV samples and identify specific viruses for further characterization, sequencing and comparative analysis was performed. A primer pair that amplifies a 414 base pair fragment of the encoding region was used to sequence the variable regions of WSSV samples. Two shrimp samples were chosen for genomic sequencing and nucleotide BLASTn analysis from both localities. The percent of identity of nucleotide sequences of our samples was 98.7\%. Comparative alignment of nucleotide sequences showed that the two samples shared similarity 95-100\% with WSSV sequences from Egypt, Korea and Taiwan.

To recognize the association of WSSV samples with further circulating WSSV, a phylogenetic tree based on the variable region nucleotide sequences of 15 WSSV that are available in GenBank included those in Egypt was constructed using the neighbourjoining method. The tree (Figure 5) showed that our samples were closely related to WSSV isolate EG24 and isolate EG55 from Egypt (KR083864 \& KR083855), WSSV isolate strain K-LV1 from Korea (JX515788) and WSSV isolate from Taiwan (AF440570)

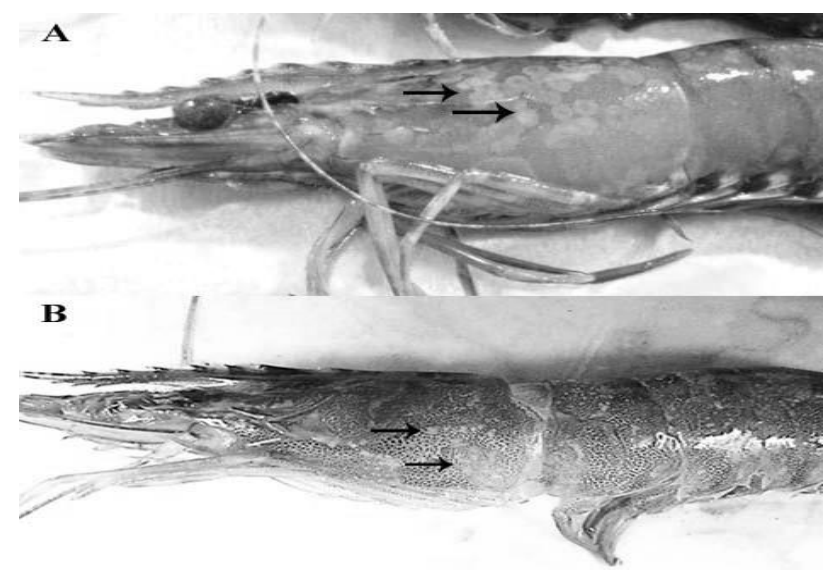

(Figure 1): Penaeus shrimps infected with WSSV: Plate (A) showing white spots coalesce to each other to form variable sized whitish circular patches 
found on the carapace and cuticle of body surface (Arrows); Plate (B) showing shell lesions range from minute spots to discs of several millimeters in diameter, and may coalesce into larger plates found on the carapace and cuticle of body surface (Arrows).

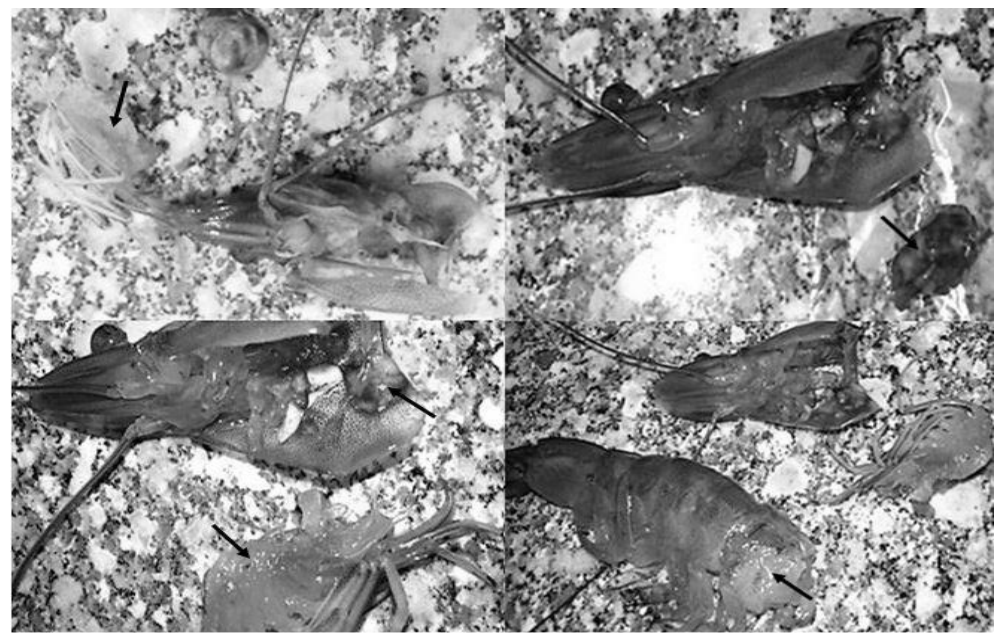

(Figure 2): Penaeus shrimps infected with WSSV where hepatopancreas become yellowish-white with swollen and fragile texture and darkening of muscles. Hemolymph was thin and hyperemic. The gills lost its preening look. Lymphoid organ may be swollen and shrunken. Swollen of bronchiostegites with accumulation of fluid. Affected shrimps appeared brown-reddish coloration.

Table 1: Gross lesions scores of WSSV in 20 collected Penaeid shrimps:

\begin{tabular}{lc}
\hline Gross lesions & WSSV \\
\hline Prominent external lesion on carapace & ++++ \\
External lesion on cephalothorax & ++ \\
White spots in inner surface of cuticle & ++++ \\
Easily detached scrapped off spots & ++++ \\
Loosely and easily separated skin & ++++ \\
Reddish discoloration & ++++ \\
Large coalescence patches of white spots & ++++ \\
Assembling of spots in beads like & ++++ \\
Cuticular deformities & + \\
Deformed rostrum bent to the left or right (Runt-deformity & - \\
syndrome) & \\
Broken and deformities of appendages & ++ \\
Darkening of abdominal muscle & ++ \\
Whitish of abdominal muscle (as cooked) & - \\
Extensive white necrotic areas of muscle & - \\
Swollen and fragile hepatopancreas & ++ \\
Thin hemolymph and fail to coagulate & + \\
\hline
\end{tabular}


The criteria of scoring were done according to Shackelford et al., (2002):

++++ Severely affected ( $100 \%$ of examined samples have lesions)

+++ Highly affected (75\% of examined samples have lesions)

+ Moderately affected (50\% of examined samples have lesions)

$+\quad$ Mild affection (25\% of examined samples have lesions)

- $\quad$ No affection (no lesion in all examined samples)

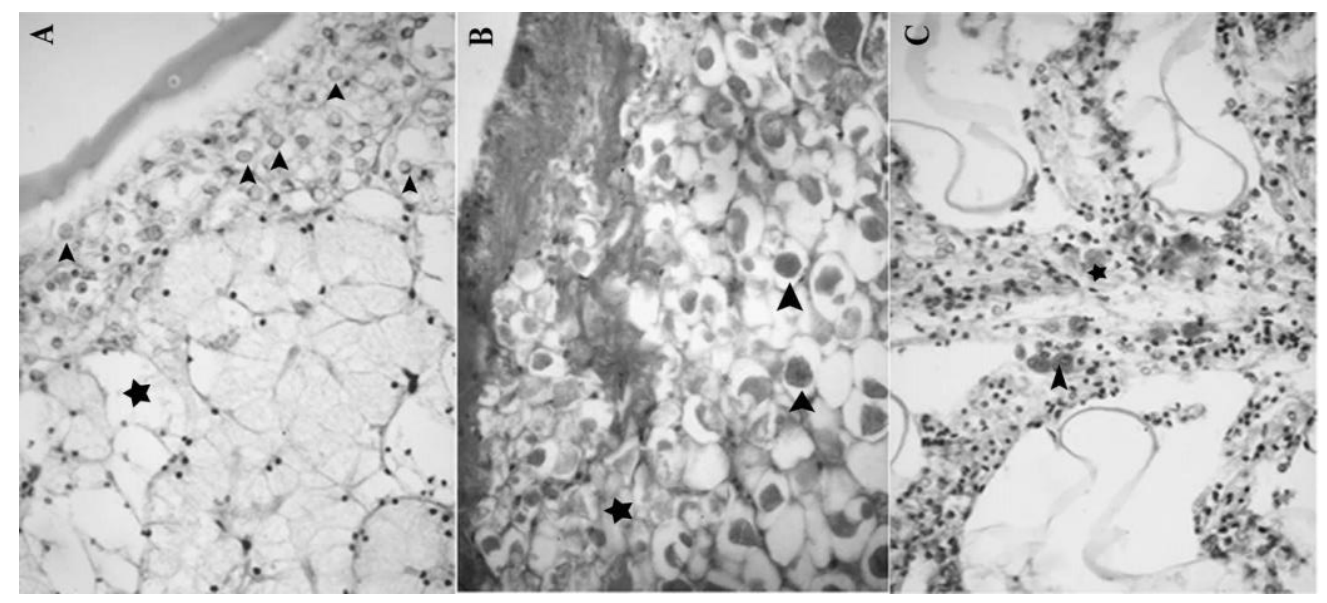

Figure 3: Histopathological examination of Penaeus shrimps infected with WSSV (H\&E). (A) Shrimp connective tissue showing cellular degeneration (Star), nuclear hypertrophy with pyknotic and karyorrhectic with eosinophilic intranuclear inclusion bodies Cowdry type A (Arrow heads) X400. (B) Shrimp muscle tissue showing cellular degeneration (Star), nuclear pyknotic and karyorrhectic with margination of chromatin and eosinophilic intranuclear inclusion bodies Cowdry type A (Arrow heads) X400. (C) Gills showing nuclear hypertrophy, pyknosis, karyorrhexis, margination of chromatin and eosinophilic intranuclear inclusion bodies Cowdry type A (Arrow head) with cellular degeneration (Star) X400.

Table 2: Histopathological lesions scores of WSSV in 20 collected Penaeid shrimp:

\begin{tabular}{lc}
\hline Histopathological lesions & WSSV \\
\hline Necrosis in dermis, epidermis & ++++ \\
I/N inclusion bodies & ++++ \\
I/C inclusion bodies & - \\
Vacuolar degeneration & +++ \\
Lymphoid organ spheroids (LOS) & ++ \\
Zenker necrosis & + \\
Cellular degeneration & +++ \\
\hline
\end{tabular}




\begin{tabular}{lc}
\hline Nuclear hypertrophy & +++ \\
Pyknosis and karyorrhexis & +++ \\
Lymphocytic infiltration & +++ \\
Accumulation of fluid (oedema) & +++ \\
Degeneration \& hyperatrophy & + \\
Inflammatory epithelioid cells & + \\
Signs of vacuolization & ++ \\
\hline
\end{tabular}

The criteria of histopathological scores were done according to Shackelford et al., (2002):

++++ Severely affected (100\% of examined samples have lesions)

+++ Highly affected (75\% of examined samples have lesions)

$++\quad$ Moderately affected (50\% of examined samples have lesions)

$+\quad$ Mild affection (25\% of examined samples have lesions)

- $\quad$ No affection (no lesion in all examined samples)

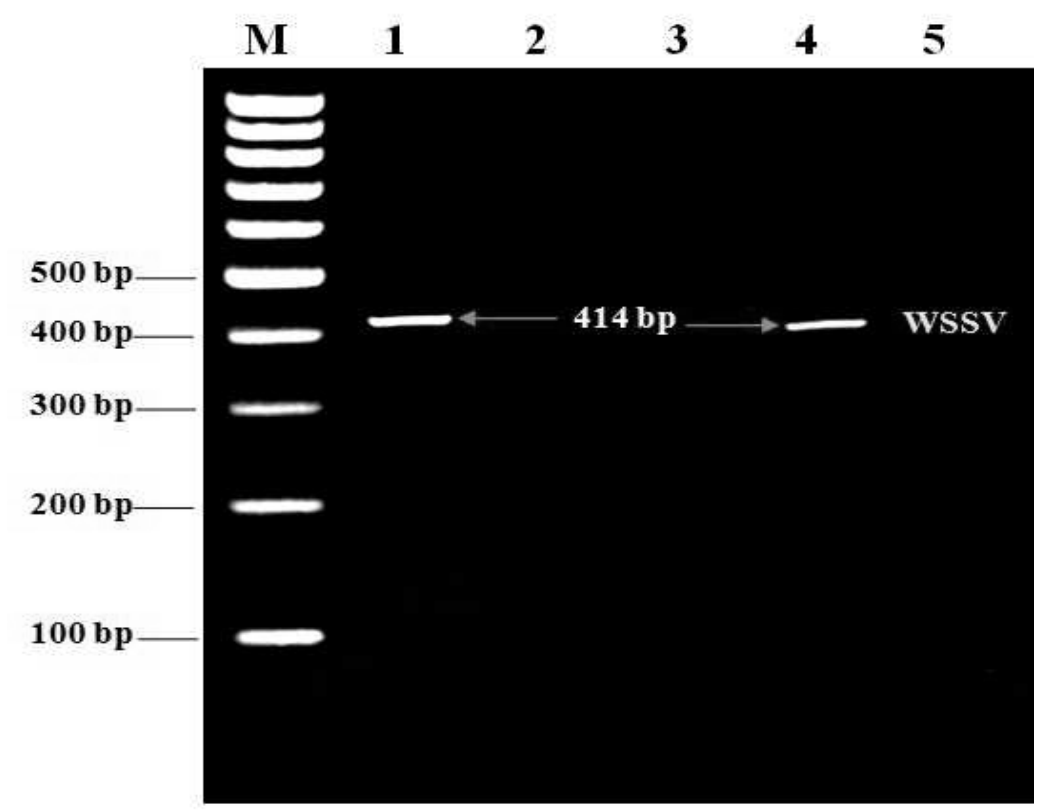

Figure 4: Molecular detection of shrimp viruses. PCR amplified products from shrimp tissues following 1.5\% agarose gel electrophoresis and ethidium bromide staining. M: DNA marker (100 bp), lane 1 and 4: Positive WSSV samples Lane 5: Negative control. 


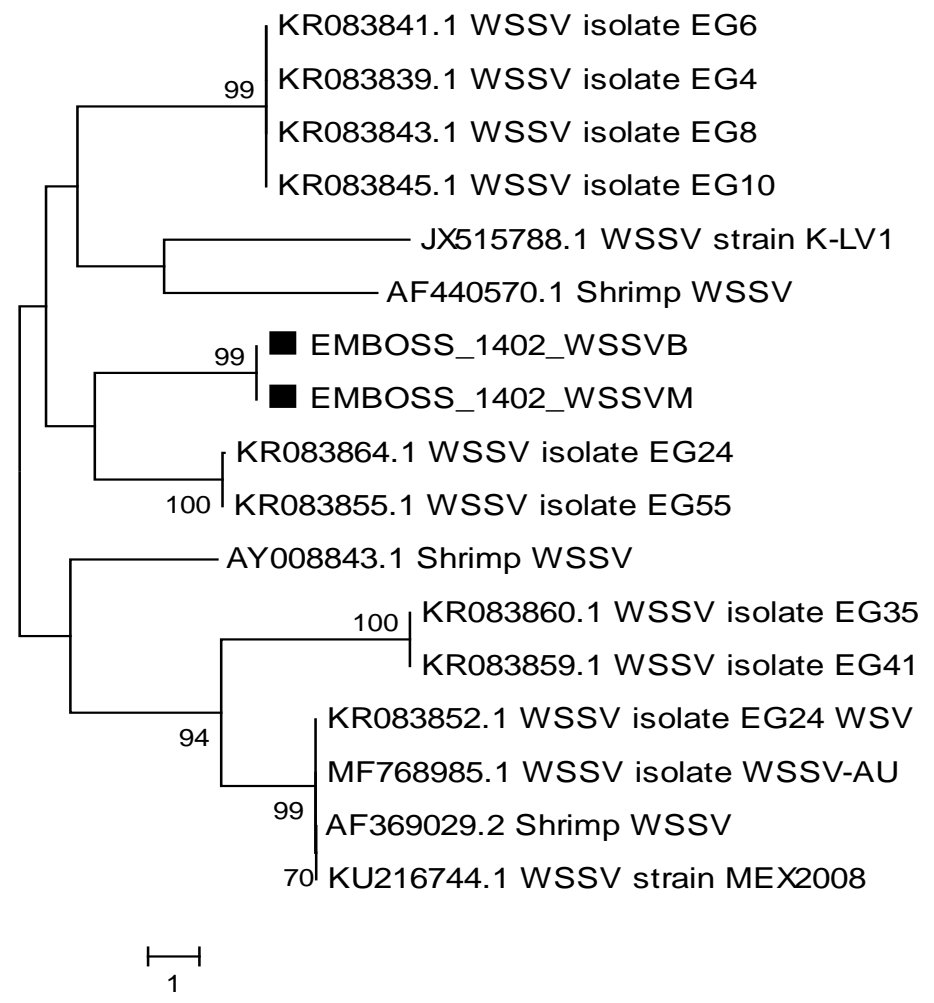

Figure 5: Phylogenetic tree of WSSV based on a partial nucleotide sequence. The tree was constructed using the Neighbor-joining method in MEGA5. The robustness of individual nodes of the tree was assessed using 1000 replications of bootstrap re-sampling of the originally aligned nucleotide sequences. Bootstrap values $\geq 70 \%$ is shown above the branches. The virus isolated in this study is marked with solid quadrilateral.

\section{Discussion}

Shrimp aquaculture has grown rapidly over several decades to become a major global industry that serves the increasing consumer demand for seafood and has contributed significantly to socioeconomic development in many poor coastal communities (Walker \& Mohan, 2009). Emerging disease epizootics frequently cause substantial, often explosive, losses among populations of shrimp, resulting in large economic losses in commercial aquaculture and threats to valuable stocks of wild aquatic animals (Walker \& Winton, 2010). A large number of pathogens threaten the shrimp aquaculture industry with a majority of these being viral in etiology so viral illnesses constitute the main problem faced by penaeid shrimp farms worldwide (Verônyca Coelho-Melo et al., 2014). In Egypt, few published studies 
addressed the shrimp diseases. Accordingly, it is important to investigate the current situation of the emerging viral diseases in shrimp farms in Egypt. To better understand the circumstances of some emerging viral diseases among shrimp farms in Egypt, Twenty shrimps were collected from Mothalath El-Deba, Damietta Province as well as Bardaweil Lake, North Sinai Province that were exhibited clinical signs of disease during 2017 and then investigated for the presence of viral infections. Under field conditions, it was possible to suspect clinically affected penaeid shrimps. The gross lesion and histopathological pictures were recorded and later confirmed by molecular detection and sequencing of the viruses.

The first approach of this work was to demonstrate the gross lesion and histopathological pictures of shrimps. The first general recognizable signs in shrimps infected with viruses were lethargic surface swimming followed by motionless, inverted sinking to the bottom, muscle opacity, lack of mobility and death similar to VegaHeredia et.al (2012) and showed a marked reduction in food consumption, followed by changes in behavior and appearance. Shrimp exhibiting this behavior may repeat the process for several hours until they become too weak to continue, or until they are attacked and cannibalized by their healthier siblings as recorded by $\boldsymbol{O I E}$ (2017).
In WSSV-infected shrimps, white spots with a diameter of 0.5 to 3.0 $\mathrm{mm}$ in the exoskeleton of the carapace, appendages and body as before declared by Haq et al. (2012).

Histopatholgical studies of WSSV implied existence intranuclear inclusion bodies Cowdry type A in cells which observed basophilic (H\&E) surrounded by marginated chromatin in hypertrophied nuclei of cells in tissues resembling to Perez et al. (2005); Afsharnasab et al.,(2009) with enlarged nuclei as stated by Flegel (2006). Nuclear hypertrophy and cellular degeneration of the cells from ectoderm and mesoderm origin were commonly observed in moribund shrimp. However, in white spot syndrome the Cowdry A inclusions represent an early stage of viral infection. Once infecting of these nuclei undergo further degeneration and finally develop into prominent eosinophilic and pale basophilic type inclusions. Existence of nuclear pyknosis and karyorrhexis in the hematopoietic tissue and lymphoid organ were accompanied with losses in tissue structure that implied attack viral infection as confirmed by Rodriguez et al. (2003).

The second approach of this work was to molecularly detect the viral infection in diseased shrimps. Tissue samples obtained from infected shrimp samples were analyzed by PCR using primer sets specific to WSSV. Although these 
methods are quite accurate, they are too expensive to be used viably as mentioned by. The PCR test developed for the shrimp aquaculture industry provide sensitive and specific methods that are also rapid and do not require extensive preparation of the tissue specimens but it is so expensive in contrast,

histopathological examination which it is more cheap as stated by Poulos \& Lightner (2006), Mello et al. (2011).

A primers set were used to detect 414 bp in WSSV which the primer was specific to VP24 gene as stated by Saberi et al. (2008) using PCR. The infected shrimps were tested and the primers were shown to be specific for WSSV and no amplicons were detected using DNA extracted from shrimp infected with other penaeid shrimp viruses as indicated by Saberi et al. (2008).

The PCR has been used to amplify a portion of WSSV genome using specific primer. It was used for definite identification of WSSV and the results showed higher sensitivity to detect the WSSV like those described before as mentioned by Poulos \& Lightner (2006). In this study, 20 samples of penaeid shrimp were collected, pooled together in 4 tubes and submitted to DNA extraction using specific primer to detect viral DNA in the tissue. Three out of four $(75 \%)$ samples were positive in WSSV from both localities; Bardaweil Lake and Mothalath El.Deba. so, these viruses with high incidence in shrimps in Egypt.

The third approach of this work was to assess genetic characteristics of WSSV via nucleotide sequencing and phylogenetic analysis. Thus, nt sequence analysis is needed to completely identify WSSV of collected samples as stated by Mello et al. (2011). The phylogenetic tree based on sequence of specific gene for WSSV of penaeid shrimp showed that samples are clustered and compared with other related nucleotide sequences on Genbank. WSSV was clustered with Egyptian sequences on Genbank because there are presenceof some records in Egypt before. The phylogenetic tree in this study found that in penaeid shrimp, WSSV of our samples was related to Egypt, Korea and Taiwan with homology 95-100\%.

\section{Conclusion:}

WSSV is a viral infection in shrimp Egyptian farms might cause high risk problems with negative impacts on the economy of the production. Gross lesion and histopathology may aid in diagnosis of WSSV among shrimp however, molecular detection; PCR and sequencing as well as phylogenetic analysis are confirmative diagnosis.

The active international trade may facilitate the dissemination of viral strains between countries including Egypt, especially in the absence of a certification as well as lack in 
implementation of regulations for the movement of free stocks.

The current results request the development of preventive measures against WSSV in penaeid shrimp.

\section{References}

Afsharnasab, M.; Mortezaei, R.; Yegane, V. and Kazemi, B. (2009): Gross sign, histopathology and polymerase chain reaction observations of white spot syndrome virus in shrimp specific pathogen free Litopeneaus vannamei in Iran. Asian J. Anim. Vet. Adv., 4: 297-305.

Alday de Graindorge, V. and Flegel, T. W. (1999): Diagnosis of shrimp diseases with emphasis on the black tiger prawn Penaeus monodon. Bangkok: FAO/Multimedia Asia Co., Ltd., Interactive CD ROM.

Bell, T.A. and Lightner, D.V. (1988): A handbook of normal penaeid shrimp histology. World Aquaculture Society, Baton Rouge, LA.

Eissa, I.A.M; Badran, A.F.H; Diab, A.S.; Saker, S.F.M and Ahmed, A.A (2009): Diagnosis of white spot syndrome virus (WSSV) among shrimp for the first time in Egypt. SCVMJ, VIX (1), 2009.

FAO, (2018): The State of World Fisheries and Aquaculture 2018 Meeting the sustainable development goals. Rome. Licence: CC BY-NC-SA 3.0 IGO.

Feijó, R.G.; Kamimura, M.T.; Oliveira-Neto, J.M.; Vila-Nova, C.M.V.M.; Gomes, A.C.S.;
Coelho, M.D.G.L. and Maggioni, R. (2013): Infectious myonecrosis virus and white spot syndrome virus co-infection in Pacific white shrimp (Litopenaeus vannamei) farmed in Brazil. Aquaculture, 380-383, 1-5. doi:

https://doi.org/10.1016/j.aquacultur e.2012.11.026

Flegel, T.W. (2006): Detection of major penaeid shrimp viruses in Asia, a historical perspective with emphasis on Thailand. Aquaculture 258, 1-33.

Flegel, T.W. (2006): The special danger of viral pathogens in shrimp translocated for aquaculture. Science Asia 32: 215-231.

Ganjoor, M. (2015): A Short Review on Infectious Viruses in Cultural Shrimps (Penaeidae Family). Fish Aquac. J. 6: 136. doi:10.4172/2150-3508.1000136

Haq, M.A.B.; Prabhuraj, V.; Vignesh, R.; Sedhuraman, V.; Srinivasan, M. and Balasubramanian, T. (2012): Occurrence of white spot syndrome virus in shrimp culturing waters and its brunt in specific pathogen free Litopenaeus vannamei with particular allusion to molecular verdicts. Asian Pacific Journal of Tropical Disease, 2(6): 431-436. doi: https://doi.org/10.1016/S22221808(12)60095-4

Lewis, R.R. III.; Phillips, M.J.; Clough, B. and Macintosh, D.J. (2003): Thematic review on coastal wetland habitats and shrimp aquaculture. Report prepared under the World Bank, NACA, WWF and 
FAO Consortium Program on Shrimp Farming and Environment. Work in Progress for Public Discussion. Published by the Consortium, pp. 81.

Lightner, D. V.; Redman, R. M.; Pantoja, C. R.; Tang, K. F.; Noble, B. L.; Schofield, P.; Mohney, L. L.; Nunan, L. M. and Navarro, S. A. (2012): Historic emergence, impact and current status of shrimp pathogens in the Americas. J. Invertebr. Pathol., 110: 174-183.

Lightner, D.V. (1996): A Handbook of Shrimp Pathology and Diagnostic Procedures for Diseases of Cultured Penaeid Shrimp. World Aquaculture Society, Baton Rouge, Louisiana, USA, 304 pp.

Lightner, D.V. (2011): Status of shrimp diseases and advances in shrimp health management. In: Diseases in Asian Aquaculture VII, Bondad-Reantaso M.G., Jones J.B., Corsin F. \& Aoki T., eds. Fish Health Section, Asian Fisheries Society, Selangor, Malaysia, 121134.

Lightner, D.V. (2011): Virus diseases of farmed shrimp in the Western Hemisphere (the Americas): A review. Journal of Invertebrate Pathology 106: 110-130.

Loy, D.S. (2014): Host-virus interactions in the Pacific white shrimp, Litopenaeus vannamei, Graduate Theses and Dissertations. Paper. p. 13777.

Loy, D.S.; Liu, S.; Mogler, M.A.; Dustin Loy, J.; Blitvich, B.J. and
Bartholomay, L.C. (2015): Characterization of newly revealed sequences in the infectious myonecrosis virus genome in Litopenaeus vannamei. J Gen Virol, 96(Pt 7): 1821-1829. doi: 10.1099/vir.0.000137

Mello, M.V.; Aragao, M.E.; Torres-Franklin, M.L.; Neto, J.M. and Guedes, M.I. (2011): Purification of infectious myonecrosis virus (IMNV) in species of marine shrimp Litopenaeus vannamei in the State of Ceara. J Virol Methods, 177(1): $10-14$.

doi:10.1/016j.jviromet.2011.05.032

OIE, (2006b): Manual of Diagnostic Tests for Aquatic Animal Diseases, 5th edition. Office International des Epizooties, Paris, France.

OIE, (2017): International Aquatic Animal Health Manual. Office International des Epizooties, Paris, France.

Pazir, M.K.; Afsharnasab, M.; Jalali Jafari, B.; Sharifpour, I.; Motallebi, A. and Dashtiannasab, A. (2011): Detection and identification of white spot syndrome virus (WSSV) and infectious hypodermal and hematopoietic necrosis virus (IHHNV) of Litopenaus vannamei from Bushehr and Sistan and Baloochestan provinces, Iran, during 2009-2010. Iranian Journal of Fisheries Sciences, 10(4): 708726.

Perez, F.; Volckaert-Filip, A.M. and Calderon, J. 
(2005): Pathogenicity of white spot syndrome virus on postlarvae and juveniles of Penaeus (Litopenaeus) vannamei. Aquaculture, 250: 586591.

Poulos, B.T. and Lightner, D.V. (2006): Detection of infectious myonecrosis virus (IMNV) of penaeid shrimp by reversetranscriptase polymerase chain reaction (RT-PCR). Dis. Aquat. Org., 73: 69-72.

Poulos, B.T.; Tang, K.F.; Pantoja, C.R.; Bonami, J.R. and Lightner, D.V. (2006): Purification and characterization of infectious myonecrosis virus of penaeid shrimp. J. Gen. Virol. 87: 987-996.

Rodriguez, J.; Bayot, B.; Amano, Y.; Panchana, F.; de Blas, I.; Alday, V. and Caleron, J. (2003): White spot syndrome virus infection in cultured Penaeus vannamei (Boone) in Ecuador with emphasis on histopathology and ultrastructure. J. Fish Dis., 26: 439450.

Saberi, A.M.; Bandehpour, M.; Afsharnasab, M.; Ghayour, E.; Yousefi Namin, S. A. and Kazemi, B., (2008): Designing and introduce a diagnostic kit for detection of white spot syndrome virus in cultured Penaeus indicus in Iran. Pakistan Journal of Biological Sciences 11: 2660-2664.

Senapin, S.; Phewsaiya, K.; Briggs, M. and Flegel, T. W. (2007): Outbreaks of infectious myonecrosis virus (IMNV) in Indonesia confirmed by genome sequencing and use of an alternative
RT-PCR detection method. Aquaculture 266: 32-38.

Shackelford, C.; Long, G.; Wolf, J.; Okerberg, C. and Herbert, R. (2002): Qualitative and quantitative analysis of nonneoplastic lesions in toxicology studies. Toxicol Pathol. 30(1): 93-6.

Stentiford, G.; Neil, D.; Peeler, E.; Shields, J.; Small, H.; Flegel, T.; Vlak, J.; Jones, B.; Morado, F. and Moss, S. (2012): Disease will limit future food supply from the global crustacean fishery and aquaculture sectors. J. Invertebr. Pathol. 110: 141-157.

Tang, K.F.J. and Lightner, D.V. (2001): Detection and quantification of infectious hypodermal and hematopoietic necrosis virus in penaeid shrimp by real-time PCR. Dis. Aquat. Org., 44: 79-85.

Tang, K.F.J. and Lightner, D.V. (2001): Detection and quantification of infectious hypodermal and hematopoietic necrosis virus in penaeid shrimp by real-time PCR. Dis. Aquat. Org., 44: 79-85.

Tang, K.F.J.; Pantoja, C.R.; Poulos, B.T.; Redman, R.M. and Lightner, D.V. (2005): In situ hybridization demonstrates that Litopenaeus vannamei, L. stylirostris and Penaeus monodon are susceptible to experimental infection with infectious myonecrosis virus (IMNV). Dis. Aquat. Organ. 63: 261-265.

Vega-Heredia, S.; MendozaCano, F. and Sánchez-Paz, A. 
(2012): The Infectious Hypodermal and Haematopoietic Necrosis Virus: A Brief Review of What We Do and Do Not Know. Transboundary and Emerging Diseases, 59(2): 95105. doi: doi:10.1111/j.18651682.2011.01249.x

Verônyca Coelho-Melo, M.; Florindo Guedes, M.I.; Rodriguez-Málaga, S.; Magalhaes De Almeida, L.; De Freitas Moreira, M. and Rodrigues De Oliveira, T. (2014): Molecular characterization of Infectious Myonecrosis Virus (IMNV) isolated from the shrimp Litopenaeus vannamei farmed in Ceará state, Brazil. Latin American Journal of Aquatic Research, 42(3): 649-652.
Vijayan, K.K. and Alavandi, S.V. (2005): Histological techniques as diagnostic tool in shrimp diseases. Central Institute of Brackish water Aquaculture, special publication, No. 26, $44-50$.

Walker, P.J. and Mohan, C.V. (2009): Viral disease emergence in shrimp aquaculture: origins, impact and the effectiveness of health management strategies. Review in Aquaculture. Vol. 1: 125-154.

Walker, P.J. and Winton, J.R. (2010): Emerging viral diseases of fish and shrimp. Veterinary Research 41(6): 51. doi: 10.1051/vetres/2010022

\section{التشخيص الباثولوجى والجزيئى لعدوى لفيروس البقع البيضاء بالجمبري في مصر

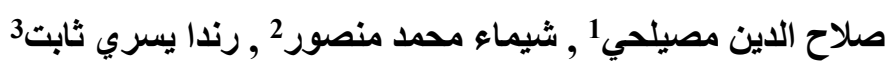

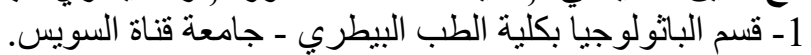

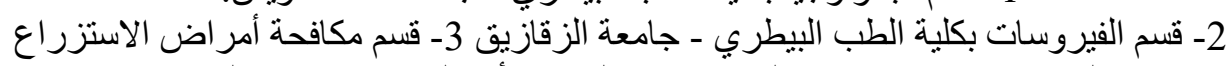 المائي بمعهد الاستزر الطع السمكي وتكنولو جيا الأسماك - جامعة قناة السويس.}

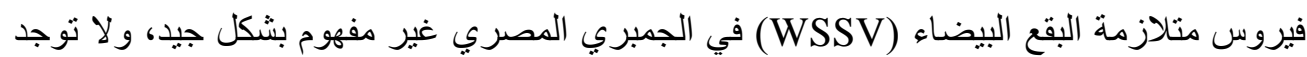

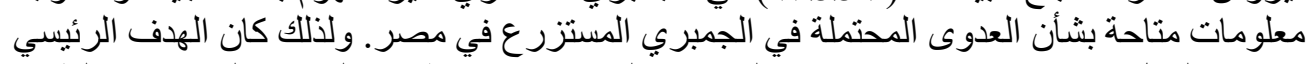

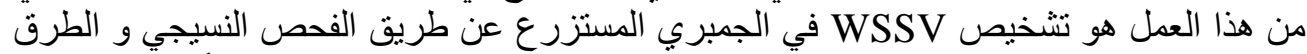

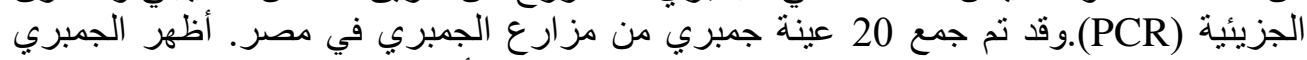

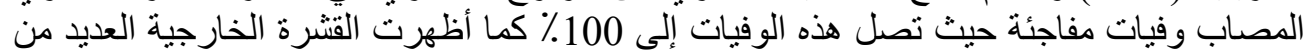

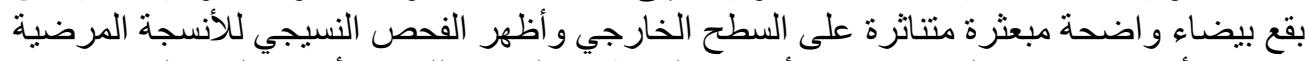

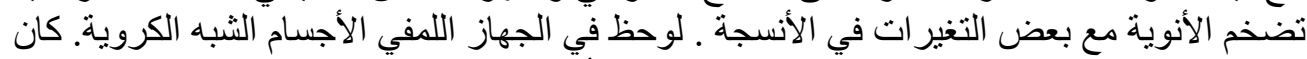

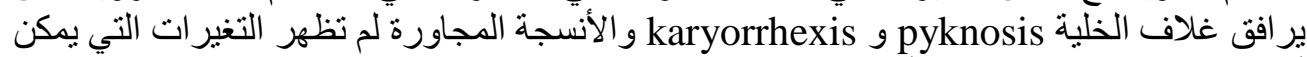

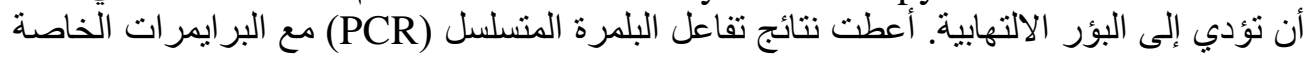

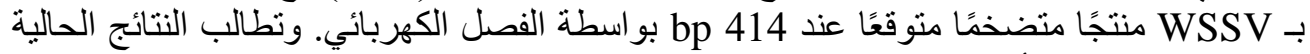

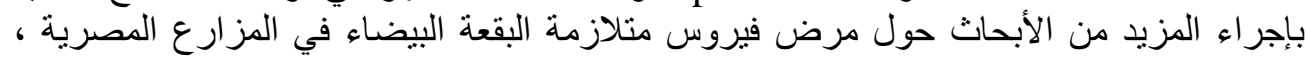
و التوصية باتخاذ تدابير وقائية ومكافحة هذا الفيروس في مصرس.

الكلمات الافتتاحية: الجمبري, مصر, فيروس مثلازمة البقع البيضاء, الفحص المرضي للانسجة, الفحص الجزيئي، تفاعل البلمرة المتسلسل، الثجرة الجينية. 